Dep. of Food Hygiene,

Animal Health Research Institute.

\title{
THE EFFECT OF HEAT TREATMENT AND \\ BACTERIAL FERMENTATION ON SOME ORGANOCHLORINE PESTICIDE RESIDUES IN RAW MILK
}

(With 4 Tables)

$$
\begin{aligned}
& \text { By } \\
& \text { HANAA H.A. EL-MOSSALAMI; SHEREIN M. NOSIER } \\
& \text { and Y.A. ABDEL-HAKEIM } \\
& \text { (Received at 11/9/2011) } \\
& \text { تأثير المعاملات المرارية والتخمر البكتيرى على متبقيات بعض المبيدات } \\
& \text { الكلورينية العضوية في اللبن الخئ الخام } \\
& \text { هناء حسينى أحدد المسلمى ، شبيرين محمود نصبير }
\end{aligned}
$$

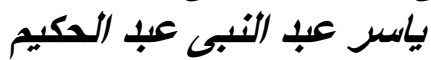

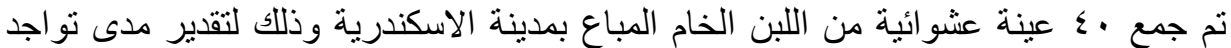

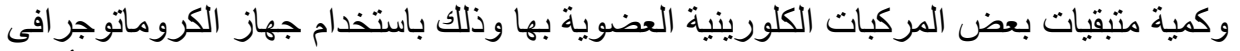

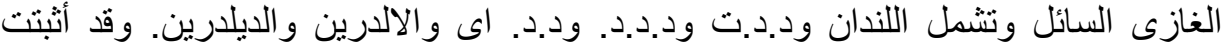

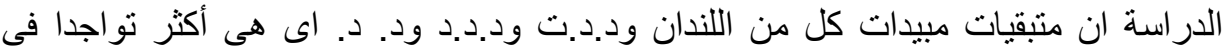

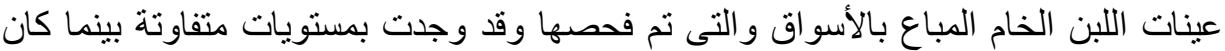

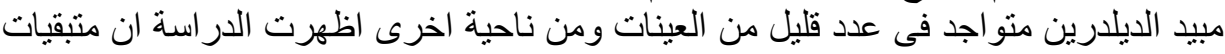

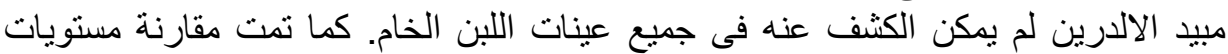

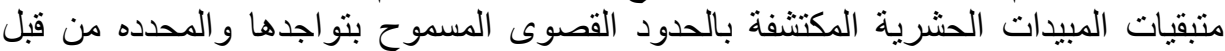

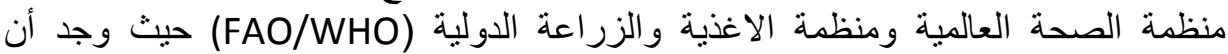

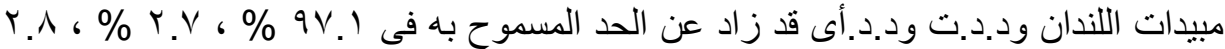

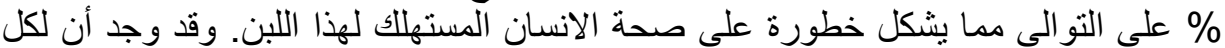

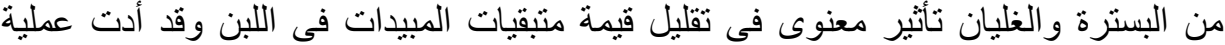

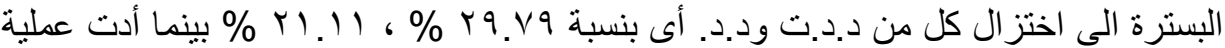

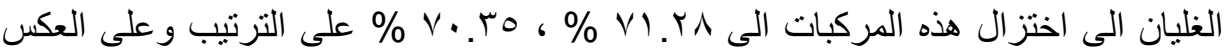

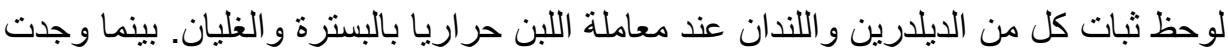

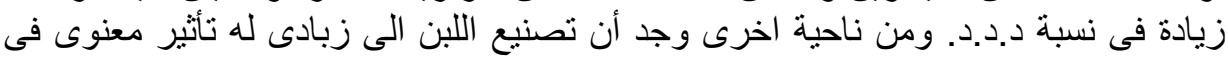

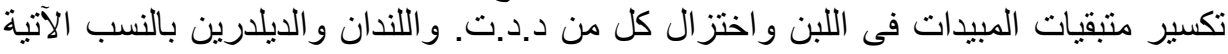




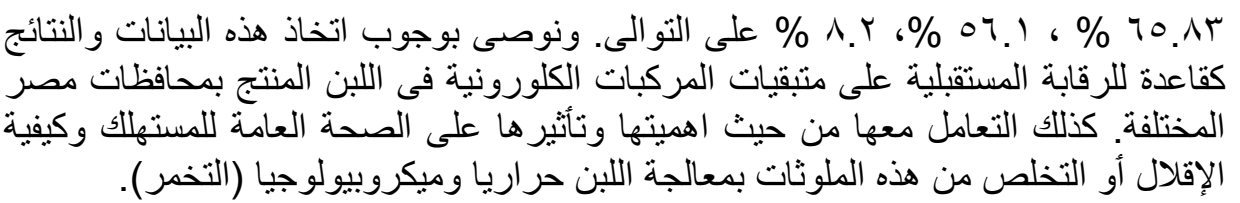

\section{SUMMARY}

A total of 40 random market raw milk samples were collected for detection of organochlorine pesticide residues using gas liquid chromatography. The obtained results from this study revealed that pesticide residues which most often found in examined milk samples were $\gamma$-HCH "lindane", P-P '-DDT, P-P '-DDD and P-P '-DDE. While residues of dieldrin could be detected in a few number of samples, on the other hand residues of aldrin could not be detected in all examined samples. The detected levels of organochlorine pesticide residues were compared with the maximum residues limits of FAO / WHO. Increasing percentages of lindane, P-P '-DDT and P-P '-DDE to $97.1 \%, 2.7 \%$ and $2.8 \%$, respectively, may act as health hazard for man consuming such milk. It has been found that both pasteurization and boiling of milk were effective in minimizing the pesticide residues. The reduction percentages of P-P '-DDT and P-P '-DDE residues were 29.79 and $21.11 \%$ in response to pasteurization. While, values of 71.28 and $70.35 \%$ were resulted by boiling. In contrast, residues of P-P '-DDD were increased, while lindane and dieldrin were relatively constant under used temperatures. On the other hand,the processing of milk into yoghurt has a significant role in degradation of the insecticide residues in milk. The reduction percentages for each DDT and lindane residues were 65.83 and $56.1 \%$ resp., while it was $8.2 \%$ for dieldrin residues. This data can be used as guidline and a base line for future monitoring of organochlorine residues in milk in the Governorates to deal with public health aspects and to minimize the organochlorine pesticides in milk by heat and microbial treatments (fermentation).

Key words: Raw milk, heat treatment, bacterial fermentation, organochlorine pesticide.

\section{INTRODUCTION}


Organochlorine Compounds (OC) are dangerous pollutants due to their toxicity, stability and solubility in fat and long term biological half life (Serrano et al., 2008). Organochlorine Pesticides (OCPs) like Dichlorodiphenyltrichloroethane's (DDTs), dieldrin, aldrin, and Hexachlorohexanes $(\gamma$-HCHs) were limited or banned chemicals by Global Stockholm Convention (Zhiwei et al., 2007 and Wang et al., 2008). The OCPs present in the environment contains agricultural and industrial chemicals (Snedeker, 2001). Appropriate and timely usage of pesticides provides a number of benefits for food production; otherwise they may become very harmful for human health. Their detection in the food and drinking water is an indication that they may enter food chain (Snedeker, 2001 and Kelly et al., 2007). The highly lipophilic features of OCPs increases their likelihood of being found in fatty foods such as milk products (Darko and Acquaah, 2008). The toxicity of OCP residues shows their effects slowly in the chose of time.

The accumulated OCP residues in the fat tissue affects some vital organs such as heart, kidneys, liver and some glands e.g., thyroid \& mammary glands and testicles (John et al., 2001; Pandit et al., 2002; Bogialli et al., 2004). While their acute toxic effects could be easily diagnosed, the effects of long term exposures could not be identified as easy as the acute one. Therefore, it is necessary to monitor their residues in the food and the environment (Darko et al., 2008). These pollutants are excreted into the milk by simple diffusion as milk is more acidic than plasma also considerable portion of milk is lipid which considered an important channel for excretion of fat soluble pesticides (Casarett and Doull, 1980; Battu et al., 2004; Jafari et al., 2008).

Up to date, no entirely safe pesticides have been developed, so the presence of significant amounts of OCP residues in milk is undesirable. As consequence these compounds have been reviewed by regulatory governmental agencies, including Food and Agriculture Organization for establishing an acceptable daily intake (ADI) and tolerance limits for pesticides (FAO/WHO, 2005). Therefore, it is plausible to throw light on the presence of OCP residues in raw market milk.

The effect of heat treatments on OCP residues occurring in raw milk have been reported by several workers (Leshchev et al., 1972; Skibniewska and Smoczynski, 1985; Korolev, 1987; Abdrabo et al., 1989; Fekry and Bahout, 1992; El-Hoshy, 1997; Zhang et al., 2005). However, the influence of milk processing on the level of OCP residues 
was determined by Mendez et al. (1979); Serjeeva (1979); Sreenivasa et al. (1983); Abdel-Shaheed (1984); Ali et al. (1993); Rajashekar et al. (2007).

The worldwide use of pesticides and their hygienic importance make it urgent to know as much as possible a more information about this subject. Therefore, this work was carried out to study:

1- The presence of organochlorine pesticide residues in raw milk in Alexandria City.

2- The influence of pasteurization and boiling on the level of pesticide residues in raw milk.

3- Effect of yoghurt processing on the content of pesticide residues in milk.

\section{MATERIALS and METHODS}

\section{* Occurrence of OCP residues in raw milk:}

\section{1 - Collection and preparation of milk samples:}

Forty composite raw milk samples were collected in triplicate from street peddlers and dairy shops in Alexandria city, Egypt. The samples were collected in glass containers of one liter capacity and immediately transferred to the laboratory for analysis. If analysis delayed for a few days, $10 \mathrm{ml}$ milk was perfectly mixed in small glass container with screw capped stoppers and kept deeply frozen at $-40^{\circ} \mathrm{C}$ for OCP residues analysis.

\section{2 - Detection of heat-treated milk:}

Each sample of raw milk was subjected to Guaiac test (Schonberg, 1956) to prove that the milk samples were raw.

\section{3 - Glass - ware:}

All glasses were prepared for analysis according to steps described by Suzuki et al. (1979); Kodba and Voncina (2007); Seccia et al. (2008).

\section{4 - Chemical and solvents:}

- Analytical grade of anhydrous sodium sulphate was dried at $135^{\circ} \mathrm{C}$ for several days prior to use.

- Florisil, PR grade (60-100 mesh) was prepared by extensive washing with water, drying at $100^{\circ} \mathrm{C}$ and then overnight firing at $550^{\circ} \mathrm{C}$, the washed, fired Florisil was kept at $135^{\circ} \mathrm{C}$ till use.

- Acetonitrile, ethanol, N-hexane, benzene and ethyl acetate were distilled from glass wares subjected to general purity test.

\section{5 - Gas liquid chromatography (GLC):}


ATI UNICAM-610 series gas chromatography with split less injector, equipped with an electron capture detector $\left(\mathrm{Ni}^{63}\right)$, flame photometric detector and ATI UNICAM chromate jet integrator was used. The injector was connected to $30 \mathrm{~m} \times 0.22 \mathrm{~mm}$ I.D. Silla capillary column containing DP-17 with 0.25 um film thickness. Nitrogen was used as a carrier gas, at flow rate of $2 \mathrm{ml} / \mathrm{min}$. The injector temperature was $260^{\circ} \mathrm{C}$ and the detector temperature was $300^{\circ} \mathrm{C}$. Split less injector was performed at oven temperature of $250^{\circ} \mathrm{C}$. The OCP residues were quantitatively determined by comparison with standard solution injected under identical GLC conditions.

\section{6 - Pesticides reference standards:}

Generally, $0.01 \mathrm{gm}$ was accurately weighed and quantitatively transferred to a $100 \mathrm{ml}$ volumetric flask as a stock standard solution using n-hexane. An aliquot from each of these stock standard solutions was diluted to a proper concentration from which a $5 \mu 1$. Injection gives a half full scale deflection peak. These working standard solution were used in determining the retention times of each of the investigated OCPs. All reference standards were kindly provided by the National Food Administration, Food Research dept., Uppsala, Sweden.

\section{7 - Organochlorine pesticides under investigation:}

Investigated pesticides includes different isomers of Hexachlorocyclohexane ( $\gamma$-HCH "lindane"), DDT complex (P-P'-DDT, P-P'-DDD \& P-P'-DDE), Aldrin and Dieldrin.

\section{8 - Extraction and clean-up procedures:}

The method used for extraction and clean-up procedures was described by A.O.A.C. (1990) and Salem et al. (2009).

\section{9 - Recovery experiment:}

Duplicate sub-samples from raw milk were subjected to all the previously mentioned steps of extraction, clean up and gas liquid chromatographic determination. To one of the duplicate sub-samples, an aliquot of the mixture contained the organochlorine pesticides standards were added. The amounts recovered from each pesticide was calculated and compared to the other duplicate to which no pesticides were spiked. The difference between the duplicates indicates the actual recovery of the pesticides.

Retention times and recovery percent of OCPs from fortified milk samples (Saad et al., 2008).

\begin{tabular}{|l|l|l|l|}
\hline Pesticides & Retention time & Fortified level & Recovery $\%$ \\
\hline \multicolumn{5}{|c}{5}
\end{tabular}




\begin{tabular}{|l|c|c|c|}
\hline & (minutes) & $(\mathrm{ppm})$ & \\
\hline Г-HCH "lindane" & 5.21 & 0.2 & 84.30 \\
\hline P-P' - DDT & 11.69 & 5.0 & 91.80 \\
\hline P-P'-DDD & 10.05 & 5.0 & 100.14 \\
\hline P-P'-DDE & 10.29 & 4.0 & 88.90 \\
\hline Aldrin & 6.15 & 0.8 & 84.14 \\
\hline Dieldrin & 8.79 & 1.6 & 98.90 \\
\hline
\end{tabular}

** Effect of heat treatments on the levels of OCP residues in milk:

1 - Pasteurization:

Five positive milk samples were heated to $62.8^{\circ} \mathrm{C}$ for $1 / 2$ hours then cooled immediately to $10^{\circ} \mathrm{C}$ (laboratory pasteurization).

\section{2 - Boiling:}

Five milk samples contained various types of present pesticide residues were heated with stirring to boiling point for five minutes then cooled.

*** Effect of yoghurt processing on the levels of OCP residues in milk:

Five positive milk samples were heated to $85^{\circ} \mathrm{C}$ in water bath for 20 minutes, cooled to $40: 42{ }^{\circ} \mathrm{C}$, inoculated with $2 \%$ yoghurt starter culture (1:1). Streptococcus thermophilous and Lactobacillus bulgaricus, then incubated at $40{ }^{\circ} \mathrm{C}$ for 3-4 hours until it was coagulated and then refrigerated over night. Yoghurt samples were then analyzed for pesticide residues.

$* * * *$ Statistical analysis:

The obtained data was analyzed statistically using F- test and Ttest according to Snedecor and Cochran (1969).

\section{RESULTS}

The obtained data are recorded in Tables $1,2,3 \& 4$.

Table 1: Residues levels of organochlorine pesticide residues in raw milk samples (ppb).

\begin{tabular}{|c|c|c|}
\hline $\begin{array}{c}\text { Pesticides } \\
\text { Residues }\end{array}$ & $\begin{array}{c}\text { Incidence } \\
\text { (Positive samples) }\end{array}$ & Levels (ppb) \\
\hline \multicolumn{2}{|c|}{6} \\
\hline
\end{tabular}


Assiut Vet Med. J. Vol. 57 No. 131 October 2011

\begin{tabular}{|l|c|c|c|c|c|}
\hline & No./40 & $\%$ & Min. & Max. & Mean \pm S.E. \\
\hline$\gamma$-HCH "lindane" & 35 & 88 & 1 & 53 & $42 \pm 0.013$ \\
\hline P-P'-DDT & 37 & 93 & 3.2 & 59 & $9 \pm 0.023$ \\
\hline P-P'-DDD & 26 & 65 & 0.56 & 29 & $3.67 \pm 0.018$ \\
\hline P-P'-DDE & 36 & 90 & 2.6 & 66 & $20.2 \pm 0.009$ \\
\hline Aldrin & 0.0 & 0.0 & 0.0 & 0.0 & $0.00 \pm 0.000$ \\
\hline Dieldrin & 6 & 15 & 0.52 & 2.93 & $1.63 \pm 0.030$ \\
\hline
\end{tabular}

Table 2: Organochlorine pesticide residues of positive examined raw milk samples on basis of maximum residues limits (MRL*).

\begin{tabular}{|l|c|c|c|c|c|}
\hline \multirow{2}{*}{$\begin{array}{c}\text { Pesticides } \\
\text { residues }\end{array}$} & $\begin{array}{c}\text { Maximum residues limits } \\
(\mathrm{MRL})(\mathrm{ppb})\end{array}$ & \multicolumn{2}{|c|}{ Within MRL } & \multicolumn{2}{c|}{ Over MRL } \\
\cline { 3 - 6 } & 10 & No. & $\%$ & No. & $\%$ \\
\hline$\gamma$-HCH "lindane" & 50 & 1 & 2.9 & 34 & 97.1 \\
\hline P-P'-DDT & 50 & 26 & 100 & 0.0 & 0.0 \\
\hline P-P'-DDD & 50 & 35 & 97.2 & 1 & 2.8 \\
\hline P-P'-DDE & 6 & 0.0 & 0.0 & 0.0 & 0.0 \\
\hline Aldrin & 6 & 6 & 100 & 0.0 & 0.0 \\
\hline Dieldrin & 6 & & & 2.7 \\
\hline
\end{tabular}

The maximum residues limits of organochlorine pesticide residues in milk proposed by FAO / WHO (2005). 
Table 3: Effect of common heat treatments on the levels of organochlorine pesticide residues in raw milk (ppb).

\begin{tabular}{|c|c|c|c|c|c|c|c|}
\hline Type of & Raw milk & \multicolumn{3}{|c|}{ Pasteurization } & \multicolumn{3}{|c|}{ Boiling } \\
\hline OCPs & Mean \pm S.E. & Mean \pm S.E. & Degradation \% & Increasing $\%$ & Mean \pm S.E. & Degrada-tion \% & Increasing \% \\
\hline $\begin{array}{l}\gamma-\mathrm{HCH} \\
\text { "lindane" }\end{array}$ & $28 \pm 0.009$ & $27 \pm 0.007 * * *$ & 1.00 & & $0.00 \pm 0.000 * * *$ & & \\
\hline P-P'-DDT & $18.8 \pm 0.037$ & $13.2 \pm 0.026 * * *$ & 29.79 & & $5.4 \pm 0.011 * * *$ & 71.28 & \\
\hline P-P'-DDD & $25 \pm 0.066$ & $31.5 \pm 0.078 * * *$ & - & 26 & $41.2 \pm 0.0098 * * *$ & & 64.8 \\
\hline P-P'-DDE & $19.9 \pm 0.053$ & $15.7 \pm 0.044 * * *$ & 21.11 & & $5.9 \pm 0.009 * * *$ & 70.35 & \\
\hline Dieldrin & $0.92 \pm 0.024$ & $0.91 \pm 0.023 \mathrm{NS}$ & 1.10 & & $0.00 \pm 0.000$ & & \\
\hline
\end{tabular}

N.B. $* * *$ very significant change between means (at $p \leq 0.001$ ) $\mathrm{NS}=$ Non significant change between means 
Table 4: Effect of yoghurt processing on the levels of organochlorine pesticide residues in raw milk ( $\mathrm{ppb}$ ).

\begin{tabular}{|c|c|c|c|c|}
\hline \multirow[t]{2}{*}{ Type of OCPs } & \multirow{2}{*}{$\begin{array}{c}\text { Raw milk (before } \\
\text { heat TTT) } \\
\text { Mean } \pm \text { S.E. }\end{array}$} & \multicolumn{3}{|c|}{ Yoghurt } \\
\hline & & Mean \pm S.E. & Loss & Degradation \% \\
\hline Total DDT & $99.8 \pm 0.109$ & $34.1 \pm 0.092 * * *$ & 65.7 & 65.83 \\
\hline Lindane & $41 \pm 0.013$ & $18 \pm 0.005^{* * *}$ & 23.0 & 56.1 \\
\hline Dieldrin & $85 \pm 0.028$ & $78 \pm 0.019 * * *$ & 7.0 & 8.2 \\
\hline
\end{tabular}

N.B. $* * *$ very significant change between means (at $\mathrm{p} \leq 0.001)$

\section{DISCUSSION}

\section{1 - Occurrence of OCP residues in raw milk:}

The residual properties and rate of the chemical which make them effective for long periods have been a cause of considerable importance in milk pollution. It is obvious clear from the results illustrated in Table 1 that $\gamma-\mathrm{HCH}$ (lindane) was present in $88 \%$ of the examined raw milk samples. The residues levels ranged from 1.0-53.0 ppb, with a mean level of $42 \pm 0.013 \mathrm{ppb}$. Similar results were obtained by El-Hoshy (1997); Francois et al. (2002); Saad et al. (2008). More or less similar levels were reported by Abouzeid (1994); Cerkvenik et al. (2000); Pardio et al. (2003).

According to the maximum residues limits recorded by FAO / WHO (2005), the results presented in Table 2 revealed that $97.1 \%$ of the examined raw milk samples containing lindane beyond the maximum residues limits. The sources of food contamination by lindane were identified by Viccellio et al. (1998) used as pesticide, scabicide and pedialocides. It was the last OCPs to be banned from agriculture practice in France in 1988 and it has been banned in Canada, United States, China, Soviet Union and Australia in 1971, 1976, 1983, 1990 and 1994, respectively, (Li, 1999 and Francois et al., 2002). Lindane still used extensively in a number of African countries, India and Brazil (Li, 1999), derived from many industries activities (Frank and Ripley, 1990) and high persistence of lindane in the environment (Uhnak et al., 1986). 
P-P'-DDT is considered one of the most important pollutants in the environment, with a potential toxicity for all biological systems, as it accumulates in human tissues. The levels of p-p'-DDT concentrations were ranged from 3.2 to $59 \mathrm{ppb}$, with a mean level of $9 \pm 0.023 \mathrm{ppb}$. $93 \%$ of examined market raw milk samples containing p-p'-DDT Table 1. Nearly similar findings were reported by Abouzeid (1994) and Saad et al. (2008), who recorded that the mean levels of p-p'-DDT were 8.902 and $9.000 \mathrm{ppb}$ in their examined milk samples,respectively. On the other hand, high figures were recorded by several workers (Cerkvenik et al., 2000; Francois et al., 2002; Waliszewski et al., 2003; Zhong et al., 2003). Lower levels were obtained by Aman and Bluthgen (1997), they mentioned that p-p'-DDT was detected with a mean level of 7.67ppb.

DDT is considered one of the most important pollutants in the environment and distributed widely in different classes of animal feeds. The major sources of DDT in the environment arise from application of DDT for control of pests in the animal feeds, flies and ectoparasites. Although DDT was banned in the early 1970, it was still manufactured in the United States and exported at rate of one ton/day for developing and tropical countries in 1994 (Smith, 1995).

It is evident from the results illustrated in Table1 that p-p'-DDD residues were detected in $65 \%$ of the examined market raw milk samples. The levels ranged from 0.56 to $29 \mathrm{ppb}$, with a mean level of $3.67 \pm 0.018 \mathrm{ppb}$. Nearly similar findings were obtained by Abouzeid (1994). On the contrary, Ali et al. (1993) and El-Hoshy (1997) recorded much higher levels of p-p'-DDD in the examined raw milk samples.

Inspection of Tablel revealed that $\mathrm{p}$ - $\mathrm{p}^{\prime}$-DDE residues were detected in $90 \%$ of samples. The values ranged from $2.6-66 \mathrm{ppb}$, with a mean level of $20.2 \pm 0.009 \mathrm{ppb}$. More or less similar levels were obtained by Awasthi and Ahuja (1995); Wong and Lee (1997); Storelli et al. (2001); Francois et al. (2002) and Bayoumi (2003). Level of DDT in milk is lower than its metabolites p-p'-DDE. These results proven that p-p'-DDT undergo several metabolic degradation to its metabolites as p$\mathrm{p}^{\prime}$-DDE (IDF, 1991). This data might indicate DDT, aging DDT stored in food results in higher p-p'-DDE concentration as derivatives Fries et al. (1972); El-Marsafy et al. (1999); Eskenazi et al. (2009).

The results displayed in Table 2 revealed that $2.7 \%, 0 \%$ and $2.8 \%$ of market raw milk samples contained $\mathrm{p}$-p'-DDT, $\mathrm{p}-\mathrm{p}^{\prime}$-DDD and $\mathrm{p}$ $\mathrm{p}^{\prime}$-DDE, respectively, beyond the maximum residues limits recorded by FAO / WHO (2005). 
It is obvious clear from the results presented in Table1 that dieldrin was detected in $15 \%$ of samples. The concentrations various from 0.52 to $2.93 \mathrm{ppb}$, with a mean level of $1.63 \pm 0.030 \mathrm{ppb}$. Similar results were obtained by Bluthgen et al. (1984); Abouzeid (1994). Considerable higher levels were recorded by El-Hoshy (1997); Wong and Lee (1997); Francois et al. (2002). On the other, Elafi et al. (1997) reported that dieldrin was not detected in any of analyzed milk samples in Libya.

Results presented in Table 2 indicated that all examined milk samples contained dieldrin within the permissible residues limits recorded by FAO / WHO (2005). Although dieldrin is used in Egyptian agriculture since 1970, it was detected at lower levels in any of analyzed raw milk samples according to FAO / WHO (2005). This may be due to that the dieldrin was destroyed by acid produced by soil bacteria (UNEP/IOC/IAEA, 1986).

The results shown in Table 1 revealed that aldrin could not be detected in all the examined raw milk samples. Similar results were recorded by Abouzeid (1994) and El-Hoshy (1997). The absence of aldrin in the examined raw milk samples could be attributed to its continuous degradation into dieldrin within the living tissues through the different metabolic process (Dogheim et al., 1988).

\section{2 - Effect of common heat treatments on the levels of natural OCP residues in milk:}

Table 3 revealed that highly significant $(p \leq 0.001)$ reduction percentages of each p-p'-DDT and p-p'-DDE residues as result of pasteurization were 29.79 and $21.11 \%$, respectively. likewise, highly significant ( $p \leq 0.001$ ), reduction of $71.28 \& 70.35 \%$, respectively, were resulted due to boiling. On the other hand, p-p'-DDD residues were highly significantly $(\mathrm{p} \leq 0.001)$, increased at percentages of $26 \%$ and $64.8 \%$ due to pasteurization and boiling, respectively. These results are in accordance with that mentioned by Abdrabo et al. (1989) and Amr et al. (1996). Moreover, the increasing level of $\mathrm{p}-\mathrm{p}^{\prime}$-DDD may be attributed to decomposing of $\mathrm{p}$ - $\mathrm{p}^{\prime}$-DDT\& $\mathrm{p}$ - $\mathrm{p}^{\prime}$-DDE during thermal treatment into $p$ - $\mathrm{p}^{\prime}$-DDD. The conversion of $\mathrm{p}$ - $\mathrm{p}^{\prime}$-DDT by thermal treatment into p-p'-DDD has reported by many authors (Hiroko et al., 1971; Dick et al., 1978; Heeschen et al., 1978). It is evident from the data illustrated in Table 3 that lindane and dieldrin residues were thermo stable against pasteurization and boiling and non significantly changed. Similar finding was determined by Abdrabo et al. (1989). 


\section{3 - Effect of yoghurt processing on the levels of natural OCP residues in milk:}

It is evident from the data illustrated in Table 4 that processing of milk into yoghurt highly significantly $(\mathrm{p} \leq 0.001)$ reduced the content of OCP residues at percentages of $65.83 \%, 56.1 \%$ and $8.2 \%$ for total DDT, lindane and dieldrin, respectively. These results are nearly similar to Ali et al. (1993). The less reduction in dieldrin residues may be attributed to inability of lactic acid bacteria to destruct this compound.

Generally, the results obtained about the efficiency of lactic acid bacteria in the degradation of pesticides in milk are coincided with those reported by Serjeeva (1979) who indicated that polluted milk with pesticides should be preferably processed into yoghurt or white pickled cheese. However, a contradictory opinion was given by Mendez et al. (1979).

From the public health point of view, organochlorines have been related to an increase in the incidence of some kinds of tumors, such as leukemia and solid tumors. Reproductive effects, due to anti-androgenic and estrogenic action, the incidence of abortion and the frequency of prematurely, have also been observed. The accumulation of the organochlorines in the adipose tissues is positively correlated to the increase in aging and could be implicated in development of aging diseases in man who consume the milk and milk products, such as Parkinson's disease who stated by Nunes-Monica and Tajara-Eloiza (1998); Bogialli et al. (2004); Cedergreen et al. (2008). DDT is suspected to being a human carcinogen, this suspicion is based on the fact that DDT has been showen to cause liver tumor in mice Edward (1993). Likewise, Helleday et al. (1996); Bulut et al. (2010), concluded that DDT has adverse effect on human health in terms of inducing genetic recombination which is known to provoke a number of diseases including Cancer. Furthermore, Langnecker et al. (1997); Soderlund et al. (2002), reported that high level exposure to selected organochlorines (including DDT) in man appeared to cause abnormal functioning of the liver, skin and nervous system. Ruehlnam et al. (1998); Sereda et al. (2009), found that DDT inhibits the L-type Ca channel in vascular smooth muscle cells and evoke rapid relaxation of coronary vasculature. Thus inhibition of calcium influx in vascular smooth muscle cells explaining the acute vasodilator action of DDT.

In conclusion, the results of this study revealed that the levels of organochlorine pesticide residues in the examined raw milk samples 
were high and over the maximum residues limits in most of the examined samples which may constitute a possible public health hazards. The predominant compounds in milk were lindane, DDT and DDE. Hence from hygienic health point of view, milk containing pesticide residues should be directed to industrial manufacturing as some of these compounds affected by boiling and pasteurization, as well as, by high acidity produced during processing of fermented milk such as yoghurt. These data can be used as guideline and a base line for future monitoring of organochlorine residues in milk in the Governorates should be done to deal with public health aspects and efforts should be directed to minimize the organochlorine pesticides contamination in milk.

\section{REFERENCES}

A.O.A.C. (1990): Official methods of analysis. $15^{\text {th }} \mathrm{ed}$, Washington Va, Chapter 10 "Pesticide Residues".

Abdel-Shaheed, Y.A. (1984): Fate of pesticides in milk and milk products. Ph. D Thesis, Fac. Agri, Alex. Univ., Egypt.

Abdrabo, F.H.; Ahmed, N.S. and Abou Dawood, A.E. (1989): Organochlorine, organophosphorus and carbamate pesticides causes changes in some properties of buffaloe's milk. Egyptian J. Dairy Sci., 17: 105-113.

Abouzeid, A.M. (1994): Studies on pesticide residues in milk and some dairy products. Ph.D. Thesis, Fac. Vet. Med., Cairo Univ.

Ali, A.A.; Metwally, M.M.; Ahmed, N.S. and Enb., A.K. (1993): Pesticide residues in milk and distribution among dairy products. Egyptian J. Dairy Sci., 21: 291-299.

Aman, I.M. and Bluthgen, A. (1997): Occurrence of residues of organochlorine pesticides and polychlorinated biphenyls in milk and dairy products from Egypt. $81^{\text {st }}$ Annual sessions of the International Dairy Federation, Reykjavik, Iceland, 27-30August 1997. Milchwissenschaft, 52(7): 394-399.

Amr, M.M.; Moursy, A.W.; Hafez, R.S.; Dogheim, S.M. and Abouzeid, A.M. (1996): Pesticide residues in milk and dairy products in Egypt. Proceeding of conference on food-borne contamination and Egyptian's health. Mansoura, Egypt, p.p. 23-39.

Awasthi, M.D. and Ahuja, A.K. (1995): Organochlorine insecticide residues in bovine milk and commercial baby milk powder. J. Food Sci. and Technology, India 32(5): 420-422. 
Battu, R.S.; Singh, B. and Kang, K. (2004): Contamination of liquid milk and butter with pesticides residues in the Ludhiana district of Punjab state, India. Ecotoxicol. Environ. Safety, 59: 324-331.

Bayoumi, A.E. (2003): Pesticides residues in milk samples collected from six markets (Shoubra, Qalyiob, Toukh, Benha, El-Kanater and Qaha) in Qalubia governorate, Egypt. Arab Universities J. Agricultural Sciences, 11(2): 868-884.

Bluthgen, A.; Heeschen, $W$. and Hijhhuis, H. (1984): Residues and contaminants in milk and milk products. Special publication, Royal Society of chemistry, (49): 206-235. Dairy Sci. Abst., (46): 8.

Bogialli, S.; Curini, R.; Di-Corcia, A.; Lagana, A.; Nazzar, M. and Tonic, $M$. (2004): Simple and rapid assay for analyzing residues of Carbamate insecticides in bovine milk: Hot water extraction followed by liquid chromatography-mass spectrometry. J. of Chromatography A, 1054(1-2): 351- 357.

Bulut, S.; Akkaya, L.; Gok, V. and Konuk, M. (2010): Organochlorine pesticide residues in butter and Kaymak in Afyonkarahisar, Turkey. J. Animal and Veterinary Advances, 9(22): 2797-2801.

Casarett, I.J. and Doull, J. (1980): "Toxicology" The basic science poisons. $2^{\text {nd }} E d$. Macmillan publishing company. New York Collier Macmillan, Canada, Ltd. Toronto, Bailiere Tindall.

Cedergreen, N.; Christenses, A.M.; Kamper, A.; Kudsk, P.; Mathiaseen, S.K. and Streibig, J.C. (2008): A review of independent action compared to concentration addition as reference models for mixtures of compounds with different molecular target sites. Environ. Toxicol. Chem., 27: 1621-1632.

Cerkvenik, V.; Doganoc, D.Z. and Jan, J. (2000): Evidence of some trace elements, organochlorine pesticides and PABs in Slovenian cow's milk. Food Technology \& Biotechnology, 38(2): 155-160.

Darko, G. and Acquaah, S.O. (2008): Levels of organochlorine pesticide residues in dairy products in Kumasi, Ghana. Chemosphere, 71: 294-298.

Darko, G.; Akoto, O. and Oppong, C. (2008): Persistant organochlorine pesticide residues in fish, sediments and water from Lake Bosomtwi, Ghana. Chemosphere, 72: 21-24.

Dick, G.L.; Heenan, M.P.; Love, J.L.; Udy, P.B. and Davidson, F. (1978): Survey of trace elements and pesticides residues in the Newzealand diet. II organochlorine and organophosphorus 
pesticide residue content. New Zealand J. Sci., 21, 71 C.F. Dairy Sci, Abst., 41(3878).

Dogheim, S.M.; Nasr, E.N.; Almaz, M.M. and El-Tohamy, M.M. (1988):

Pesticide residues in milk and fish samples collected from two Egyptain Governorates. J. Assoc. Off. Anal. Chem., 73, 1.

Edward, A. (1993): Aquatic pollution: An Introductory Text. $2^{\text {nd }}$ Ed. John Wiley \& Sons, INC, INY, USA.

Elafi, A.; Rahmani, M. and Abdennebi, E.H. (1997): Contamination of commercial milk by organochlorine pesticides in Libya. Assiut Vet. Med. J., 36(72): 306-312.

El-Hoshy, S.M. (1997): Insecticide residues in milk and influence of heat treatments and bacterial fermentation as safeguard against these pollutants. Assiut Vet. Med. J., 37 (73): 141-155.

El-Marsafy, A.M.; Alla, S.A.; Zidan, M.A.; Fahmy, S.M. and Dogheim, S.M. (1999): Monitoring of organochlorine pesticide residues in milk products. Egyptain J. Agricultural Research, 77(1): 205-216.

Eskenazi, B.; Chevrier, J.; Goldman, R.L.; Anderson, A.A.; Bornman, M.S. and Bouwman, H. (2009): The Pine River statement: Human health consequence of DDT use. Environ. Health Perspect, 117: 1359-1367.

FAO/WHO "Food and Agriculture Organization/World Health Organization" (2005): Plant production and protection paper, 122: 31-33. Geneva, 20-29 September.

Fekry, F.M. and Bahout, A.A. (1992): Effect of heat treatment on milk contaminated with diazinon as an environmental pollutant. The new Egyptian Journal of Medicine, 7(2): 367-372.

Francois, B.; Dary, I. and Marc, F. (2002): Inter laboratory study of a multiresidue gas chromatographic method for determination of organochlorine, pyrethroid and polychlorobiphenyls in milk, fish, eggs and beef fat. J. Association of Official Analytical Chemists (AOAC), 85(6): 1398-1409.

Frank, R. and Ripley, B. (1990): Food residues from pesticides and environmental pollutants in Ontario, In O.J. Nriago and M.S. Simmons (Ed.). Food contamination from environmental sources. J. Wiley and Son Inc., Ontario, Canada. 473-524.

Fries, F.; Marrow, D. and Gordon, C. (1972): Similarity of polychlorinated biphenyl (Arcolor) and DDT in rate of elimination from cows. Australian Vet. J., 60(9): 820-835. 
Heeschen, W.; Bulthgen, A. and Tolle, A. (1978): Residues of chlorinated hydrocarbons in milk and milk products. Situation and evaluation. Infekions Krankheiten and Hygiene, IB (1976) 126(1/2): 188-197. C.F. Dairy Sci. Abst., 38(1914).

Helleday, T.; Tonminen, K.L.; Bergman, A. and Jenssen, D. (1996): Brominated flame retardant induces intragenic recombination in mammalian cells. Nutri.Res., 439(2) 19: 137-147.

Hiroko, K.; Deloach, E. and Hemphill, D.D. (1971): Effect of cooking utensils composition and contents on the reductive dechlorinated of DDT to DDD. J. Asso. of. Anal. Chem., 54: 1352.

IDF "International Dairy Federation" (1991): Monograph on residues and contaminants in milk and milk products, 5: 101-103.

Jafari, A.; Moeckel, C. and Jones, K.C. (2008): Spatial biomonitoring of persistent organic pollutants in Iran: A study using locally produced butter. J. Environ. Monitor, 10: 861-866.

John, P.J.; Bakore, N. and Bhatnagar, P. (2001): Assessment of organochlorine pesticide residues levels in dairy milk and buffalo milk from Jaipur City, Rajasthan, India. Environ. Int., 26: 231-236.

Kelly, B.C.; Ikonomou, M.G.; Blair, J.D.; Morin, A.E. and Gobas, F.A. (2007): Food web-speciefic biomagnifications of persistant organic Pollutants. Science, 317: 236-239.

Kodba, Z.C. and Voncina, D.B. (2007): A rapid method for the determination of organochlorine, pyrethroid pesticides and polychlorophenyls in fatty food using GC with electron capture detection. Chromatographia, 66: 619-624.

Korolev, B.A. (1987): Decontamination of milk containing pesticides residues. Hygiena Sanitariya, (7): 29-31.

Langnecker, M.P.; Rogan, W.J. and Lucier, G. (1997): The human health effect of DDT and PCBs and an overview of organochlorines in public health. Annual Review of public health. (18): 211-244.

Leshchev, V.Vr.; Kan, P.T. and Talanov, G.A. (1972): Excretion of Dursban and Diazinon with milk. Veterinariya, Moscow, USSR No.10: 114-115.

Li, Y.F. (1999): Global technical hexachlorocyclohexane usage and its contamination consequences in the environment from 1984 to 1997. Sci. Total Environ., 232: 121-158. 
Mendez, A.; Martnez, C.I. and Jarez, M. (1979): Possibilities of eliminating organochlorine pesticide residues from milk and milk products. Revista Espanalo de Lecheria, No. 114: 213-228.

Nunes-Monica, V. and Tajara-Eloiza, H. (1998): Delayed effects of organochlorine pesticides in man. Revista de sande publica, 32(4): 372-382.

Pandit, G.G.; Shrma, S.; Srivastava, P.K. and Sahu, S.K. (2002): Persistent organochlorine pesticide residues in milk and dairy products in India. Food Addit. Cont., 19: 153-157.

Pardio, V.T.; Waliszewski, S.M.; Landin, L.A. and Bautista, R.G. (2003): Organochlorine pesticide residues in cow's milk from a tropical region of Mexico. Food Additives and Contaminants, 20(3): 259-269.

Rajashekar, K.; Kondal, R.K.; Narasimha, R.K. and Sudhakar, R.K. (2007): Effect of processing of milk into products on the residue levels of certain pesticides. J. Food Sci. Tech., 44: 551-552.

Ruehlnam, D.O.; Sfiner, J.R.; Valvende, M.A.; Jacob, R. and Mann, G.F. (1998): Environmental estrogenic pollutants induce acute vascular relaxation by inhibition L-type $\mathrm{Ca} 2+$ Channels in smooth muscle cells. FASEB Journal 12(7): 613-619.

Saad, A.H.; Abdel-Hakiem, E.H.; El-Zeni, S. and El-Nabarawy, E.A. (2008): Prevalence of some organochlorine pesticide residues in market milk. Assiut Vet. Med.J., 54(116): 119-132.

Salem, N.M.; Ahmad, R. and Estaitieh, H. (2009): Organochlorine pesticide residues in dairy products in Jordan, Chemosphere, 77: 673-678.

Schonberg, F. (1956): Milch - Kunde and Milch hygiene, 7, Auffage, Verlarg M. and H. Scheber, Hannover, Germany.

Seccia, S.; Fidentey, P.; Montesano, D. and Morrica, P. (2008): Determination of neonicotinoid insecticides residues in bovine milk samples by solid phase extraction clean-up and Liquid chromatography with diode-array detection. J. chromatography A, 1214(1-2): 115-120.

Sereda, B.; Bouwman, H. and Kylin, H. (2009): Comparing water, bovine milk and indoor residual spraying as possible sources of DDT and pyrethroid residues in breast milk. J. Toxicol. Environ. Health A, 72(13): 842-851.

Serjeeva, D. (1979): Effect of ordinary and technological processing of milk containing organophosphorus and cabamate pesticides. 
Khranitelna pronishlenost, 27-28. C.F. Dairy Sci. Abst., 43: (2803).

Serrano, R.; Barreda, M. and Blanes, M.A. (2008): Investigating the presence of organochlorine pesticides and polychlorinated biphenyls in wild and farmed gilthead sea bream (sparus aurata) from the Western Mediterranean Sea Marine Pollut. Bull., 56: 63-972.

Skibniewska, K.A. and Smoczynski, S. (1985): Influence of storage and thermal processing on stability of certain organophosphate insecticides in milk. Milchwissenschaft, 40(2): 84-85. C. F. Dairy Sci. Abst., 47, 6.

Smith, K. (1995): Pesticide exported from U.S.A., 1992-1995. Los Angeles: Foundation for advancement in Sciences and Education.

Snedecor, G.W. and Cochran, W.G. (1969): Statistical methods. Sixth E.d., Iowa State Univ., press Iowa.

Snedeker, S.M. (2001): Pesticides and breast cancer risk: A review of DDT, DDE and dieldrin. Eviron. Health Perspect., 109: 35-47.

Soderlund, D.M.; Clark, J.M.; Sheets, L.P.; Mullin, L.S.; Piccirillo, V.J. and Sargent, $D$. (2002): Mechanisms of pyrethroid neurotoxicity: Implications for cumulative risk assessment. Toxicology, 171: 3-59.

Sreenivasa, E.R.; Bluthgen, S. and Yokomdo, N.W. (1983): Effect of different processing on levels of pesticide residues in milk. J. Milk and Food Technology. 45(11): 1017-1020.

Storelli, M.M.; Storelli, A. and Marcorigiano, G.O. (2001): Polychlorinated biphenyls, hexachlorobenzene and organochlorine pesticide residues in milk from Apulia, Italian. J. Food Sci., 13(1): 113-117.

Suzuki, T.; Ishikawa, K.; Sats, N. and Sakal, K. (1979): Determination of xhlorinated pesticide residues in foods. J. Assoc. Off. Anal. Chem., 3, 62 .

Uhnak, J.V.; Madaric, M.A. and Szokolay, A. (1986): Dynamic of hexachlorobenzene residues in the food chain. Proceedings of an international Symposium (IARC Scientific Publication No.77), C.R. Morris and J.R.P. Cabral (Ed.) International Agency for research on cancer, Lyon: 109-113.

UNEP/IOC/IAEA. (1986): Determination of DDTs and PCBs by capillary gas chromatography/electron capture detection. Reference method for marine pollution studies. No: 40, UNEP. 
Viccellio, P.; Brent, J.; Hoffman, R.S. and Kulig, K.W. (1998): Emergency toxicology $2^{\text {nd }}$ Ed. School of Medicine, New York, 401-413.

Waliszewski, S.M.; Villalobos-Pietrini, R.; Gomez-Arroyo, S. and Infanzon, R.M. (2003): Persistant organochlorine pesticide levels in cow's milk samples from tropical regions of Mexico. Food Additives and Contaminants, 20(3): 270-275.

Wang, Z.; Yan, W.; Chi, J. and Zhang, G. (2008): Spatial and vertical distribution of organochlorine pesticides in sediments from Daya Bay, South China. Marine Pollu. Bull., 56: 1578-1585.

Wong, S. and Lee, W. (1997): Survey of organochlorine pesticide residues in milk in Hong Kong (1993-1995). J. A.O.A.C. International, 80(6): 1332-1335.

Zhang, Y.; Muench, S.B.; Schulze, H.; Perz, R.; Yang, B.; Schmid, R.D. and Bachmann, T.T. (2005): Disposable biosensor test for organophosphate and insecticides in milk. J. Agric. Food Chem., 53(13): 5110-5115.

Zhiwei, Y.; Lubica, P.; Beata, D.; Jan, P.; Anton, K.; Tomas, T. and Irva, H.P. (2007): Comparison of organochlorine compound concentrations in colostrums and mature milk. Chemosphere, 66: 1012-1018.

Zhong, W.; Dian-Dou, X.; Chai, Z.; Mao, X.; Zhong, W.K.; Chai, Z.F. and Mao, X.Y. (2003): Survey of organochlorine pesticides in retail milk from Beijing, P.R. China. Food Additives and Contaminants, 20(3): 254-258. 
Assiut Vet Med. J. Vol. 57 No. 131 October 2011 